Conference Paper

\title{
Analysis of Corporate Value in Manufacturing Companies
}

\author{
Supriandi*, Yusuf Iskandar, Ujang Setiawan \\ Nusa Putra University, West Java, Indonesia
}

*Corresponding author:

E-mail:

Supriandi_mn18@nusaputra.ac.id

\begin{abstract}
This study aims to be able to find out and provide information on the development of manufacturing industries that dominate companies registered in the Indonesian Securities Foam (BEI) to find out the value of the company in the Consumer Goods Consumer Cosmetics and Household Utilities Industry sector. Method: The author in this study uses a measurement tool to determine the value of the company that is the Tobins'Q ratio, Data Analysis: This study used 7 comics and household goods sub-sector companies listed on the Indonesia Stock Exchange (IDX) from 2017-2019 with information that can be accessed on the official website www.idx.com. Results and Discussion: The results of this study indicate that there are still companies that have a company value below one or are categorized as a low company (undervalued), but of 7 companies 5 companies have a Tobins' $Q$ value of above 1 which means it has the potential to have potential growth. Conclusion: The author is optimistic that the Cosmetics and Households Sub-sector companies have better growth potential in the future and can have Tobins'Q values above 1 for 7 of these companies, the authors have the view that the stock prices that have been published by manufacturing companies are sufficient good but every year it fluctuates, increasing company performance to get high company value must be increased so that the company's profitability increases every year.
\end{abstract}

Keywords: Corporate value, Tobins'Q Ratios

\section{Introduction}

The Manufacturing Industry is an industry that is experiencing a good and rapid increase, we can find this out through access to the official website of the Indonesia Stock Exchange where manufacturing companies record-high profits ( www.idx.co.id) the manufacturing industry dominates. The manufacturing industry whose development is very fast makes new stakeholders want to own a company in the manufacturing sector, of course, competition with new and old competitors occurs, course very fierce competition will make the manufacturing industry crowded, intense competition will make each company improve performance so as not lose in the market. The company was established, of course, has a clear objective. There are three objectives of the company, the first is to achieve good profits and margins. The second company goal is where the maximum profit is the goal to prosper and the welfare of company owners or shareholders, the third goal of the company is to maximize the value of the company as reflected in its share price. The company value can be maximized as seen from the price of shares per sheet in the market which will attract investors to join in investing in the company. There is a picture of the market wealth of the owner and shareholder of the company (Poitras, 1994).

According to Islam et al. (2014) argues that the price per share represents the shareholder, the company has been a renowned course in terms of their company furthers the goal is to maximize value through improving the welfare of the p hold shares. According to Fau (2015) Company value is important because it is an indicator of how the market assesses the company as a whole, the existence of Company Value is something that affects the prosperity that is very satisfying for shareholders if in its development the share price increases or increases. After all, owner companies can't have high wealth 
if the companies they own do not have good corporate values. Enterprise Value (EV) in another language is the firm value (company value) is a very important concept for an investor, it is said to be very important because it is an indicator for the market to assess a company as a whole.

The value of the company occurs, of course, due to the satisfied community's trust in the company. Noerirawan and Muid (2018) argues that corporate value is a condition that has been achieved by a company as an illustration of public trust in the company after going through a process of activity for several years, namely since the company was founded until now. Of course, the value of a company is greatly influenced by the profitability of the company, where to see its profitability can be seen transparently by knowing the stock price and financial performance is one of the indicators to show how a company uses its assets, of course, to be able to obtain maximum profit. Financial Statements or the Annual Report is a thing that is most important for the company as an enterprise tool for taking decisions that are strategic in the very useful future and a policy for the company. Of course, the contents of a financial report must contain very high-value information for users, especially transparency and accountability. The Annual Report is unlikely to have an impact that will at least attract investors to make an assessment stock valuation process which will reflect the relationship between risk and return following the respective stock types www.idx.co.id, 2020).

The Tobins' $Q$ ratio is very superior to the ratio of market value to book value, it is said to be superior because this ratio focuses on the value of the company in relative terms at this time. The shows that the greater Tobin's Q value indicates that the company has good growth prospects. The occurrence of this is due to the large market value and assets of the company when compared to the book value of assets in that company, which will allow investors to make more sacrifices so that these investors can own the company. Classic q-theory of investment predicts that Tobin's q, the ratio of capital's market value to its replacement cost, perfectly summarizes a firm's investment opportunities.

\section{Literature Review \\ The value of the company}

The company's value Understanding the value of the company according to the author's view that the assessment of investors to the company that the indicator is the value of the Company and other indicator is the stock price in the market. The company value can be said to be high if the share price is high, while the company value according to the expert, the company value is the investor's perception of the company, which is often associated with the stock price. Where the value of shares can be defined by the number of shares multiplied by the market value per share plus the debt value, so if the debt value is constant, automatically or directly the share value will greatly increase the company's value.

Referring to Sultan (2014) financial statement analysis is one way to determine the company's performance in a period. The company's financial performance can be measured using financial ratios. Financial ratios will show the movement of changes in financial conditions and the potential to manage company assets to increase company value. The company's value will be the view or benchmark for investors on the success of a company in managing its resources. Share prices are how stock prices are traded and occur in the capital market. For companies that have issued their shares and are listed on the capital market, this is a very important indicator to maximize company value. Therefore, the cycle will always be the higher the stock price, the higher the company value will be direct. This is in line with Moniaga (2013), which states that the share price is the price that occurs when shares are traded on the market.

Every company certainly has a desire to be known more widely, especially companies that have gone public, of course, the thing that must be considered is maintaining the good name of the company by maximizing company value, of course, to find out the achievement of management performance which will be a benchmark with the prosperity of shareholders, because the higher the value of the company, the shareholders are guaranteed to be prosperous. Investment decisions are certainly influenced by financial performance, decisions regarding funding or capital, as well as asset decisions, which are of course guided by the goal they want to achieve, namely to maximize company value 


\section{Variable of firm value}

A brief history of Tobin's Q or Q ratio or Q theory is the ratio or theory first introduced and discovered by an American named in 1969. James Tobin is a well-known economist in America and his hypothesis is in the field of economists who are capable of delivering success to get the Nobel Prize. Tobin's Q also explains that the value of a company is the combined value of tangible assets with intangible assets. This is in line which states that the market value of a company should be the same as the cost of replacing the company's assets so that it creates an equilibrium condition with the market value of the company, which means the market is less assessing the company. Tobin's $Q$ value of a company that has a high number is at number 1 which indicates that the company value is higher in value than the value of the assets of the company that is registered and that is not measured or recorded.

\section{Material and Methods}

Table 1. List of manufacturing companies on the IDX

\begin{tabular}{|c|c|c|c|c|}
\hline No. & Sector & Subsector & $\begin{array}{l}\text { Number of } \\
\text { Companies }\end{array}$ & Total \\
\hline \multirow{9}{*}{1} & \multirow{9}{*}{$\begin{array}{l}\text { Basic Industry } \\
\text { and Chemicals }\end{array}$} & Cement & 6 & \multirow{9}{*}{77} \\
\hline & & Ceramics, Porcelain, and Glass & 8 & \\
\hline & & Metals and the like & 17 & \\
\hline & & Chemistry & 12 & \\
\hline & & Plastics and Packaging & 15 & \\
\hline & & Animal feed & 4 & \\
\hline & & Wood and Processing & 4 & \\
\hline & & Pulp and Paper & 9 & \\
\hline & & Others & 1 & \\
\hline \multirow{6}{*}{2} & \multirow{6}{*}{$\begin{array}{l}\text { Miscellaneous } \\
\text { Industry Sector }\end{array}$} & Automotive and Components & 13 & \multirow{6}{*}{51} \\
\hline & & Machinery and Heavy Equipment & 5 & \\
\hline & & Textiles and Garment & 21 & \\
\hline & & Footwear & 2 & \\
\hline & & Cable & 7 & \\
\hline & & Electronic & 3 & \\
\hline \multirow{6}{*}{3} & \multirow{6}{*}{$\begin{array}{l}\text { Goods and Con- } \\
\text { sumption Indus- } \\
\text { try Sector }\end{array}$} & Food and Drink & 25 & \multirow{6}{*}{52} \\
\hline & & Cigarettes & 5 & \\
\hline & & Pharmacy & 10 & \\
\hline & & Cosmetics Household goods & 7 & \\
\hline & & Household appliances & 4 & \\
\hline & & Others & 1 & \\
\hline
\end{tabular}

Source: www.sahamoc.com

This research is a quantitative descriptive study designed to collect information about firm value at 7 manufacturing companies. This study aims to determine the value of the Cosmetics and Household Goods Manufacturing companies listed on the Indonesia Stock Exchange using the Tobins' Q or Q Ratio. The reason the writer uses Tobin's $Q$ ratio is that the writer has the view that the Tobins ' $Q$ ratio can be counted on to provide the best information. The author also uses the Tobins'Q Ratio as an alternative to measuring Firm Value in addition to the Price Earning Ratio (PER) and the Price to Book Value (PVB) Ratio. The author chooses the Cosmetics and Household Goods subsector because this subsector is a subsector that provides the needs of the community.

This research was conducted at the company level, namely all cosmetic and household goods subsector manufacturing companies which can be obtained through the official website of the Indonesia Stock Exchange (IDX), namely www.idx.co.id with a period of using data from 2017 to 2019 which 
was carried out for 2 effective months. The companies that are the research samples to be studied are manufacturing companies in the consumer goods industry sector, the Cosmetics and Household Purposes sectors listed on the Indonesia Stock Exchange can be seen in Table 2.

Table 2. List of manufacturing companies cosmetics and household goods sub-sector

\begin{tabular}{llll}
\hline No. & Stock code & Company name & Date I PO \\
\hline 1 & ADES & Akasha Wira Indonesia Tbk & 13 June 1994 \\
2 & KINO & Kino Indonesia Tbk & December 11, 2015 \\
3 & KPAS & Cottonindo Ariesta Tbk & October 5, 2018 \\
4 & MBTO & Martina Berto Tbk & 13 June 2011 \\
5 & MRAT & Mustika Ratu Tbk & 27 July 1995 \\
6 & TCID & Mandom Indonesia Tbk & 23 September 1993 \\
7 & UNVR & Unilever Indonesia Tbk & January 11, 1982 \\
\hline
\end{tabular}

Source: www.sahamoc.com

\section{Data analysis}

Tobins' $Q<1$ indicates that the book value of the company's assets is greater than the market value of the company, a low share price will be the main objective of the company to be acquired and merged with other companies, because of the liquidation of the company's stock value. in the low category and appreciated the low (undervalued).

Tobins' $Q>1$ indicates that the value of the company shows that the market value company higher than the book value of the assets, thus indicating that the company has high growth potential so that the value of the company is more than just the value of its assets (overvalued).

Tobins' $Q=1$ shows that the market value of the company is the same as the book value of the asset, this shows that the company is in an average condition.

\section{Results and Discussion}

One indicator in assessing or seeing how a company is in a healthy condition and worthy of being the main investment objective or not, namely the indicator is the value of the company, of course, the value of the company is one of the important goals of the establishment of a company because the higher the value of the company. then the level of prosperity and welfare of the company founders and shareholders is guaranteed. A high share price is a reflection of the company value of a company and can increase the attractiveness of investors to invest in a company. In this study, to measure the value of the company will use a formula or measure Tobin's $Q$ ratio. Tobin's $Q$ ratio is considered to provide the best information because Tobin's Q includes all the elements of debt and share capital of the company, not just ordinary shares and not just equity. included companies, but all company assets (Riyadi, 2018).

Table 3. Market capitalization value for cosmetics and household goods

\begin{tabular}{cccc}
\hline Company & 2017 & 2018 & 2019 \\
\hline ADES & 522.058 .668 .000 & 542.705 .056 .000 & 616.442 .156 .000 \\
KINO & 3.028 .571 .580 .000 & $4,000.000 .200 .000$ & 4.900 .000 .245 .000 \\
KPAS & - & 426.240 .000 .000 & 49.922 .780 .830 \\
MBTO & 144.450 .000 .000 & 134.820 .000 .000 & 100.580 .000 .000 \\
MRAT & 88.168 .000 .000 & 76.612 .000 .000 & 65.484 .000 .000 \\
TCID & 3.599 .093 .339 .300 & 3.468 .400 .005 .750 & $2,211.733 .337 .000$ \\
UNVR & 426.517 .000 .000 .000 & 346.402 .000 .000 .000 & 320.460 .000 .000 .000 \\
\hline
\end{tabular}

Source: www.edusaham.com 
Based on Table 3 above it can be seen that the value of the market capitalization of the manufacturing companies in 2017 a market capitalization sorted from the value of the highest to the lowest value contained in the company, UNVR, TCID, KINO, ADES MBTO, and a market capitalization lowest is found in the company MRAT. In 2018 the market capitalization value is sorted from the highest market capitalization value to the lowest value, namely UNVR, KINO, TCID, ADES, KPAS, MBTO companies, and the lowest market capitalization value, which is found in MRAT companies. Likewise in 2019, the market capitalization value is sorted from the highest market capitalization value to the lowest value, namely UNVR, KINO, TCID, ADES, MBTO, MRAT companies, and the lowest market capitalization value, which is found in KPAS companies.

Table 4. Book value of total payable (debit)

\begin{tabular}{cccc}
\hline Company & 2017 & 2018 & 2019 \\
\hline ADES & $417,225,000,000$ & $399,361,000,000$ & $366,549,000,000$ \\
KINO & $1,182,424,339,165$ & $1,405,264,079,012$ & $1,992,902,779,331$ \\
KPAS & $101,342,835,628$ & $94,403,627,595$ & $107,478,494,828$ \\
MBTO & $367,927,139,244$ & $347,517,123,452$ & $355,892,726,298$ \\
MRAT & $130,623,005,085$ & $143,913,787,087$ & - \\
TCID & $503,480,853,006$ & $472,680,346,662$ & $532,048,803,777$ \\
UNVR & $13,733,025,000,000$ & $11,944,837,000,000$ & $15,367,509,000,000$ \\
\hline
\end{tabular}

Source: https://www.idx.co.id/

Based on Table 4 above it can be seen that the book value of total debt (debit) in manufacturing companies in 2017 the value of debit sorted from the value the highest to the lowest value contained in the company UNVR, KINO, TCID, ADES, MBTO, MRAT and debt the lowest is found in KPAS companies. In 20018, debits (book value of total debt) were sorted from the highest to the lowest values found in the companies UNVR, KINO, TCID, ADES, MBTO, MRAT, and the lowest debt was found in KPAS companies. In 2019, debits (book value of total debt) are sorted from the highest value to the lowest value found in UNVR, KINO, TCID, ADES, MBTO companies, and the lowest debit is found in KPAS companies.

Table 5. Total asset

\begin{tabular}{llll}
\hline Company & $\mathbf{2 0 1 7}$ & $\mathbf{2 0 1 8}$ & $\mathbf{2 0 1 9}$ \\
\hline ADES & $840,236,000,000$ & $881,275,000,000$ & $865,873,000,000$ \\
KINO & $3,237,595,219,274$ & $3,592,164,205,408$ & $4,695,764,958,883$ \\
KPAS & $188,274,009,952$ & $230,724,365,283$ & $240,856,984,154$ \\
MBTO & $780,669,761,787$ & $648,016,880,325$ & $591,063,928,037$ \\
MRAT & $497,354,419,089$ & $511,887,783,867$ & - \\
TCID & $2,361,807,189,430$ & $2,445,143,511,801$ & $2,551,192,620,939$ \\
UNVR & $18,906,413,000,000$ & $19,522,970,000,000$ & $20,649,371,000,000$ \\
\hline
\end{tabular}

Source https://www.idx.co.id/

Based on table 5, manufacturing companies in 2017, the total asset value, sorted from the highest value to the lowest value, is found in UNVR, KINO, TCID, ADES, MBTO, MRAT companies, and the lowest total assets are KPAS companies. In 2018, total assets were sorted from the highest asset value to the lowest value, namely the companies UNVR, KINO, TCID, ADES, MBTO, MRAT, and the lowest total asset value, which is found in KPAS companies. Likewise in 2019, total assets were sorted from the highest total asset value to the lowest value, namely the UNVR KINO, TCID, ADES, MBTO companies, and the lowest market capitalization value, which was found in KPAS companies. 
To find a description of the company value as proxied by the Tobins'Q value, data analysis was carried out based on a statistical description of the firm value of the research sample. Statistical descriptions are used to determine the amount of data $(\mathrm{N})$ used in this study and can show the maximum value, minimum value, and average value of the research variables. Based on the results of descriptive statistical data processing that has been carried out using the help of the Microsoft Excel 2013 program, the results are obtained as can be seen in Table 6 .

Table 6. Tobins'q analysis results

\begin{tabular}{lllll}
\hline \multirow{2}{*}{ No } & \multirow{2}{*}{ Code } & Year & $\mathbf{2 0 1 8}$ & $\mathbf{2 0 1 9}$ \\
\cline { 3 - 5 } & & $\mathbf{2 0 1 7}$ & 1.06 & 1.13 \\
\hline 1 & ADES & 1.11 & 1.50 & 1.46 \\
2 & KINO & 1.30 & 2.2 & 0.65 \\
3 & KPAS & - & 0.74 & 0.77 \\
4 & MBTO & 0.65 & 0.43 & - \\
5 & MRAT & 0.43 & 1.41 & 1.07 \\
6 & TCID & 1.73 & 18.3 & 16.2 \\
7 & UNVR & 23.2 & 0.43 & 0.65 \\
\hline Lowest Tobins'Q & 0.43 & 18.3 & 16.2 \\
Highest Tobins'Q & 23.2 & 23.50 & 38.27 \\
\hline
\end{tabular}

Source: Data Processed, 2020

Based on the results of the research on the calculation of Tobins'Q for company value, namely the Cosmetics and Household Purposes sub-sector companies listed on the Indonesia Stock Exchange (IDX) for the 2017-2019 period, the data shows that there are still companies that have a Tobins'Q value which is below 1 Company that is below 1 and consistently do not experience an increase in the value of Tobins'Q, namely the company PT. Mustika Ratu Indonesia, Tbk (MRAT), the book value of the company's assets is greater than the market value of the companies owned by MRAT. This is the main reason why MRAT companies are included in the category of companies that have low values. Even though they still have a low Tobins' $Q$ value, manufacturing companies can still operate and can survive to make a profit like PT. Martino Berto, Tbk (MBTO) and PT. Mustika Ratu Indonesia, Tbk (MRAT), besides that company that have a Tobins'Q calculation of more than 1 but fluctuate in the 2017-2019 period, namely the company Akasha Wira Indonesia, Tbk (ADES), PT. Kino Indonesia, Tbk (KINO), Mandom Indonesia (TCID) and PT. Unilver Indonesia. High company value or above 1 is due to the company's market value being higher than the book value of the company's assets. Although fluctuating, the company has the potential to increase the growth of its corporate value. The author can assume that the Cosmetics and Household Purposes sub-sector companies have a Tobins'Q value of more than 1 or the bias indicates the company is good, of course, to invest for investors in the company, there are 5 companies out of 7 samples that have a Tobins' $Q$ value of more than one. Cosmetics subsector and household needs, especially PT. Mustika Ratu (MRAT), which has a Company Value with a Tobins'Q ratio below 1 , must be able to take advantage of and maximize the company value with market capitalization value that must be increased.

\section{Conclusion}

In this study, the authors conclude that the manufacturing companies listed on the Indonesia Stock Exchange, namely the Consumer Goods Industry sector, the Cosmetics, and Household Goods subsector, there are still companies that have a Tobins' $Q$ value that is below 1 and the company is included in the low company value category. (undervalued). The cosmetics and household goods sub-sector has 4 companies that have been listed on the Indonesia Stock Exchange (IDX) for a long time, namely the 
company UNVR 1995, TCID 1993, MRAT 1995, ADES 1994, although the company has been around for a long time, the company value of the 4 companies that have been making cross is inconsistent or fluctuate very well as a fairly young company has the date of the IPO at the Indonesia Stock Exchange (BEI), a company KINO 2015, MBTO 2011, KPAs 2018 still has a value of less than 1. the author suggests Tobins' $Q$ in research This is for manufacturing companies that have been listed on the Indonesia Stock Exchange as investment companies have the opportunity to continue to develop as well as industries that have many companies should be biased to maintain and to improve company performance which will have an impact on company value so that the company will be confident in competing with competitors la ins so that it has very high competitiveness. The author is optimistic that the Cosmetics and Household Utilities sub-sector companies have better future growth potential and can have a Tobins'Q value above 1 for the 7 companies, the author has the view that the stock prices that have been published by manufacturing companies are quite good but every year it fluctuates, improving company performance to get a high company value must be further improved so that the company gains annual profits.

\section{Acknowledgment}

First authors would like to thanks so much to Prodi Management, University of Nusa Putra Sukabumi which has provided the opportunity to obtain research data, so this study can be run well and the author would like to give thanks to ICEMAC $1{ }^{\text {st }}$ for the opportunity that has been given to writers to be able to participate and participate

\section{References}

Fau, N. R. (2015). The influence of capital structure, company growth, company size and profitability on firm value in manufacturing companies listed on the indonesia stock exchange. Essay. Yogyakarta: Yogyakarta State University.

IDX. (2020). Indonesia stock exchange. Retrieved: https://www.idx.co.id

Islam, Md. R., Khan, T. R., Choudhury, T. T., \& Adnan, A. M. (2014). How Earning Per Share (EPS) affects on share price and firm value. European Journal of Business and Management, 6(17), 97-108.

Moniaga, F. (2013). Capital structure, profitability and cost structure on company value for ceramic, porcelain and glass industry 2007 2011. In the EMBA Journal, 1(4), 433-442.

Noerirawan, M. R., \& Muid, A. (2018). The influence of internal and external factors on firm value (empirical study on manufacturing companies listed on the Indonesia stock exchange 2007-2010 period). Diponegoro Journal of Accounting, l1(2), 1-12.

Poitras, G. (1994). Shareholder wealth maximization, business ethics and social responsibility. Journal of Business Ethics, 13(2), 125-134. DOI:10.1007/BF00881581 